\title{
Functionality of the Family System in the Perception of Adolescent Stu- dents with Different Levels of Creative Attitudes
}

\author{
Irena Pufal-Struzik \\ Jan Kochanowski University in Kielce, Poland \\ E-mail address: irenapufal@gmail.com
}

\author{
Agnieszka Szewczyk \\ Jan Kochanowski University in Kielce, Poland \\ E-mail address: asutowicz@onet.eu
}

\section{ARTICLE INFO}

\section{Keywords:}

Family factors in creativity

A systems approach

\section{Article history:}

Received 23 October 2013

Received in revised form 6 December 2013

Accepted 22 December 2013

ISSN:

DOI: $10.15290 /$ ctra.2014.01.01.08

\section{A B STRACT}

\section{INTRODUCTION}

In nurturing the creativity of gifted children, the family may provide the environmental context that stimulates or sparks creativity, rewards creative ideas and behaviours, and evaluates creative products (Sternberg \& Lubart, 1993). Some studies have concluded that the family plays an important and positive role in the development of talents and potential of gifted children (e.g. Albari, Smadi, Bani Yassin \& Al Schammari, 2013; Bloom, 1985; Csikszentmihalyi, Rathunde \& Whalen, 1993; Goertzel, Goertzel \& Goertzel, 1978; Helson, 1968; Hennessey, 1995; Mendecka, 2003; Miller \& Gerard, 1979; Olszewski, Kulieke \& Buescher, 1987; Paris \& Helson, 2002; Pufal-Struzik, 2006).

Evidence for the supporting role of the family in the development of creativity was provided, amongst others, by a longitudinal study of children aged 3-5 years and then at the age of 11-14 years (Harrington, Block \& Block, 1987) and by studies examining the retrospections of creative adults who, as a rule, had received support from 
their parents in childhood (Walberg, Rasher \& Parkerson, 1980). A more stimulating effect may be had by families which successfully solve situational and developmental crises as compared to those families which cannot effectively deal with crises (Russell, 1979). So it can be assumed that experiences related to one's family play a significant role in the development of creative abilities.

Over the last few decades, systems theory has gained a great deal of interest and recognition among family researchers, emphasising the view that the development of the individual is the result of an interaction between various dimensions of family life (Cox \& Paley, 2003; Rostowska \& Rostowski, 2006). According to Olson's Circumflex Model (Olson, 2000), the family is a system that functions in three dimensions: cohesion, flexibility and communication that occur with varying intensity and in different configurations, which results in the uniqueness of each family system. The functional family system is characterized by positive emotional ties, skills to adapt to the changing conditions of family life, efficient communication processes, lack of both developmental difficulties and the disintegration of family life and a general sense of the functionality of family members. A manifestation of the difficulties a family experiences (a dysfunctional family system) can be enhanced by pathogenic family roles, experiencing developmental difficulties, lack of mutual understanding and a general lack of a sense of family functionality (Gaś, 1994). The systems perspective is also applied to the search for the relationship between environmental factors within family and the development of creative attitudes in adolescents (Mendecka, 2003). In our research we aimed at answering the question: what are the positive and negative traits of family functioning in the perception of adolescents with different levels of creative attitudes? The following research hypotheses were adopted:

Hypothesis 1: There is a positive relationship between the creative attitude of adolescents and their perception of the positive dimensions of family functioning.

Hypothesis 2: There is a negative relationship between the creative attitude of adolescents and their perception of the negative dimensions of family functioning.

\section{METHOD}

\section{Participants}

The research was conducted in the school year 2011/2012. The study involved adolescents from secondary schools from the city of Kielce. The sample group was drawn from four randomly selected secondary schools. A total of 335 persons participated. The complete material collected from 297 individuals (including 169 girls and 128 boys) aged about 16 years to 18 years was selected for analysis. Most of the re- 
spondents were adolescents who had completed 17 years of age ( $91 \%$ of respondents). The age group from which the subjects were drawn allows for the presumption that they have a rich experience of family interaction and that at the same time, they are able to take a more objective view of the nature of the functioning of their families during their childhood and adolescence (cf. Csikszentmihalyi, Rathunde \& Whalen, 1993).

\section{Instruments}

The Family Profile Inventory (FPI designed for persons over the age of 15 years), developed by Gaś (1994), consists of 86 statements that form six scales, of which three concern the positive aspects of the family system (family cohesion [FC], adaptiveness [AD], mutual understanding [MU]), while three other scales concern the difficulties experienced by families (family roles [FR], developmental difficulties [DD], family disintegration [FD]). Based on the results of the Family Profile individual test scales, conclusions are made about the global level of the sense of family functioning. The sense of family functionality (SF) is the ratio of the sum of the scores on the scales of the positive dimensions of family functioning to the sum of the scores on scales that describe the difficulties in family functioning, in accordance with the conception of the author of the inventory, calculated according to the formula $S F=(F C+A D+M U) /(F R+D D+F D)$. The task of the investigated subject was to assess the degree of accuracy of each statement referring to his or her family. The basis of the inventory is a circumplex model. Reliability was assessed using the absolute stability index (calculated separately for children, mothers and fathers), the values of which are in the range from .35 to .90 . The most stable scales are family cohesion (FC) and family roles (FR), and the lowest level of stability was found in the mutual understanding scale (MU) and the sense of functionality scale (SF), being mostly dependent on ad hoc life experiences related to the functioning of the family system (Gaś, 1994).

The KANH I Questionnaire (for people aged over 13 years ), developed by Stanislaw Popek (2010), consists of 60 statements that make up the four lower order scales: conformity $(\mathrm{C})$, nonconformity $(\mathrm{N})$, heuristic behaviour $(\mathrm{H})$ and algorithmic behaviour $(\mathrm{A})$, which give two factors of a higher order - creative and reproductive attitude. From this perspective, creative attitude is a dynamic construct, which consists of nonconformity and heuristic behaviour. Nonconformity (including such items as: independence, originality, courage, self-organization) refers to the personal characteristics of creative attitude and heuristic behaviours (including the following features: independence of observation, divergent thinking, cognitive activity, constructive and verbal creativity, as well as potential talent for artistic creativity) represent the intellectual sphere. In turn, conformism (as evidenced by such features as dependency, passivity, stereotypy, sub- 
missiveness) and algorithmic behaviours (e.g. convergent thinking, intellectual rigidity, lack of technical and artistic ingenuity) are characteristic of the reproductive attitude. The questionnaire allows for the diagnosis of general creative and imitative skills in the field of cognitive and motivational personality because the statements contained therein are associated with a variety of human actions taking place in the process of activity or in learning situations. The questionnaire includes, amongst others, such statements as: I aim to apply well proven and established ways of behaviour, work rules, play forms, as well as common morals (scale C); I try to solve a variety of tasks and any difficulties according to known principles (scale A); I go my separate way, and I try to perform my tasks differently from my peers (scale N); I try to act prudently, and I am not influenced by the models adopted by others, but I make my own rules of conduct (scale H) (Popek, 2010). KANH I is one of the most successful instruments of measurement in the Polish psychology of creativity (Karwowski, 2013). The reliability of the individual scales of the questionnaire was estimated at .72 (scale C), .69 (scale N), .69 (scale H), and .65 (scale A), calculated as the reliability of the latent variable in a confirmatory factor analysis (Karwowski, 2013).

\section{Procedure}

Students were investigated during two class periods, with an interval of about two weeks. Correlation and regression analysis were used for the analysis. Kendall's nonparametric correlation coefficient was calculated by estimating the strength of the relationship between the level of creative and reproductive attitudes of adolescents and the intensity of positive and negative features of family system functioning perceived by the subjects.

\section{RESULTS}

Family functionality in the perception of the investigated adolescents was inferred on the basis of the scales of the Family Profile Inventory. The positive dimensions of the functioning of the family environment are assessed by the following scales: family cohesion, which refers to a sense of community, emotional intimacy, or possession of solid family values and beliefs; adaptiveness, which includes, amongst others, such dimensions as coping with family problems and the ability to constructively use inferences from past experiences in future; and mutual understanding, which concerns family empathy, mutual understanding of the motives and behaviour of family members or being open to other people's messages. A manifestation of the difficulties that arise in family systems can be pathogenic family roles of interrelated identities, family development difficulties, as evidenced by schematism of action, stagnation, pessimism, life helplessness, hopelessness in situations of crisis for particular family members and family disintegration, which leads to difficulties such as the family being unable to unite in crisis situations 
and increases in the family's sense of threat, as well as levels of dysfunctionality. The indicator of a global sense of family system functionality is the result of the perception of the individual characteristics of family functioning in both positive and negative dimensions (Gaś,1994).

In turn, the level of creative and reproductive attitudes of the investigated subjects was evaluated by the Creative Behaviour Questionnaire KANH I, developed by Stanislaw Popek. The level of creative attitudes of adolescents was inferred on the basis of the intensity of nonconformist-heuristic behaviours disclosed by adolescents and the level of imitative attitudes was determined on the basis of conformist-algorithmic behaviours. Table 1 shows descriptive statistics of the results obtained.

\section{TABLE 1}

Descriptive statistics for results on the FPI and KANH I

\begin{tabular}{|c|c|c|c|c|c|c|c|c|c|}
\hline \multirow[b]{2}{*}{ Dimensions offPI } & \multicolumn{9}{|c|}{ Descriptive statistics ( $N=297)$} \\
\hline & $M$ & Me & Min. & Max. & $S D$ & $s$ & $\boldsymbol{V}$ & $\kappa$ & $A$ \\
\hline family cohesion $\langle 0 ; 40\rangle^{a}$ & 23.1 & 23.0 & 0.0 & 40.0 & 8.9 & 78.5 & 38.4 & -0.6 & -0.3 \\
\hline adaptiveness $<0 ; 34>$ & 22.9 & 24.0 & 0.0 & 34.0 & 8.4 & 71.3 & 36.9 & -0.3 & -0.7 \\
\hline mutual understanding $\langle 0 ; 28\rangle$ & 19.9 & 21.0 & 4.0 & 27.0 & 4.7 & 21.8 & 23.3 & 0.7 & -0.9 \\
\hline family roles $<0 ; 50>$ & 20.4 & 20.0 & 2.0 & 46.0 & 9.5 & 89.6 & 46.4 & -0.8 & 0.1 \\
\hline developmental difficulties $\langle 0 ; 18>$ & 7.2 & 7.0 & 0.0 & 18.0 & 3.9 & 14.4 & 53.1 & -0.3 & 0.3 \\
\hline family disintegration $\langle 0 ; 20\rangle$ & 6.2 & 5.0 & 0.0 & 20.0 & 5.3 & 27.8 & 84.4 & -0.3 & 0.8 \\
\hline sense of family functionality & 2.8 & 2.0 & 0.2 & 13.1 & 2.3 & 5.2 & 82.2 & 3.9 & 1.8 \\
\hline Scales of KANH I & $M$ & Me & Min. & Max. & $S D$ & $s$ & $\boldsymbol{v}$ & $\kappa$ & $A$ \\
\hline Conformism $<0 ; 30>$ & 12.7 & 13.0 & 2.0 & 25.0 & 4.3 & 18.7 & 34.0 & -0.2 & 0.2 \\
\hline algorithmic behaviour $<0 ; 30>$ & 14.8 & 15.0 & 6.0 & 24.0 & 3.6 & 12.7 & 24.0 & -0.4 & -0.1 \\
\hline non-conformism $<0 ; 30\rangle$ & 19.5 & 20.0 & 9.0 & 29.0 & 4.1 & 17.1 & 21.2 & -0.2 & -0.2 \\
\hline heuristic behaviour $\langle 0 ; 30\rangle$ & 18.1 & 18.0 & 8.0 & 28.0 & 3.9 & 15.3 & 21.6 & -0.4 & -0.1 \\
\hline
\end{tabular}

Note. $\mathrm{M}$ - mean, Me - median, Min. - minimum value in a set, Max. - maximum value in a set, SD - standard deviation, $\mathrm{s}$ - variance, $\mathrm{V}$ - coefficient of variation, $\mathrm{K}$ - kurtosis, A - coefficient of skewness.

${ }^{a}$ Theoretical range of scale.

A correlation analysis was used for determining the relationship between the positive and negative dimensions of the functioning of the family system and a global sense of family functionality and the components of creative and reproductive attitudes. The corresponding correlation coefficients for the relationships and interrelationships between the $\mathrm{FPI}$ scales and relationships within the KANH I scales are presented in Table 2. 


\section{TABLE 2}

The correlation matrix between the individual subscales of the FPI and the KAHN I

\begin{tabular}{|c|c|c|c|c|c|c|c|c|c|c|c|}
\hline Variable & $F C$ & $A D$ & $M U$ & $F R$ & $D D$ & $F D$ & $S F$ & $C$ & $A$ & $N$ & $H$ \\
\hline$\overline{F C}$ & 1.00 & $.53^{*}$ & $.48^{*}$ & $-.22^{*}$ & $-.37^{*}$ & $-.50^{*}$ & $.55^{\star}$ & .04 & $.09^{*}$ & -.02 & - \\
\hline$A D$ & & 1.00 & $.50^{*}$ & $-.34^{*}$ & $-.50^{*}$ & $-.65^{\star}$ & $.70^{*}$ & - & .05 & .04 & .04 \\
\hline MU & & & 1.00 & $-.24^{*}$ & $-.37^{*}$ & $-.49^{*}$ & $.53^{*}$ & .04 & $.10^{*}$ & -.02 & - \\
\hline FR & & & & 1.00 & $.17^{\star}$ & $.32^{*}$ & $-.57^{\star}$ & $.12^{*}$ & -.02 & .01 & .07 \\
\hline DD & & & & & 1.00 & $.41^{*}$ & $-.48^{*}$ & -.07 & -.02 & $-.11^{*}$ & $-.10^{*}$ \\
\hline FD & & & & & & 1.00 & $-.66^{\star}$ & .02 & -.05 & .00 & -.06 \\
\hline SF & & & & & & & 1.00 & -.04 & .05 & .02 & .02 \\
\hline C & & & & & & & & 1.00 & $.28^{*}$ & $-.19^{*}$ & $-.08^{*}$ \\
\hline A & & & & & & & & & 1.00 & -.05 & -.04 \\
\hline $\mathrm{N}$ & & & & & & & & & & 1.00 & $.36^{*}$ \\
\hline $\mathrm{H}$ & & & & & & & & & & & 1.00 \\
\hline
\end{tabular}

Note. FC - family cohesion, AD - adaptiveness, MU - mutual understanding, FR - family roles, DD - developmental difficulties, FD - family disintegration, SF - sense of family functionality, C - conformism, $\mathrm{A}$ - algorithmic behaviour, $\mathrm{N}$ - non-conformism, $\mathrm{H}$ - heuristic behaviour. * $\mathrm{p}<0,05$

Values of Kendall's $\tau$ were calculated in relation to the deviation from the normal distribution of results in the scales for adaptiveness, mutual understanding, developmental difficulties, family disintegration, sense of family functionality, algorithmic behaviour, nonconformism, and heuristic behaviour. In accordance with the character of the areas of family life described by the FPI scales, significant positive correlations between the scales for family cohesion, adaptability, mutual understanding and a sense of global functionality of the family were obtained. Similarly, statistically significant positive correlations were found for the scales relating to: the pathogenic role of the family, developmental difficulties within the family and disintegration of the family.

The negative relationships between the positive dimensions of family system functioning and the negative dimensions of family functioning were also statistically significant. The positive correlation coefficients among the scales that comprise the creative attitude, as well as positive correlations among the scales measuring reproductive attitudes, with negative dependencies between the components of creative and reproductive attitudes also confirm the reliability of the KANH I.

The correlation analysis used to test the relationships between the results of the FPI scales and the KANH I results confirmed that the higher the level of creative attitude of the respondents, i.e. stronger manifestations of heuristic behaviour and non-conformism, the less often were developmental difficulties perceived in their families as a negative aspect of family life. It was also observed that the higher the level of algorithmic behaviour of the respondents, the more likely they were to feel greater family cohesion and mutual 
understanding based on specific empathy between family members. Algorithmic behaviour, as a manifestation of reproductive attitude, correlates positively with two positive dimensions of family functioning, while, conformity, which belongs to the realm of the characterological sphere of reproductive attitude, coincides with the perception of pathogenic roles in the family.

In the next stage of the analysis, multiple regression was used to determine the predictors of dimensions of family functioning from the perspective of the adolescents. In constructing the regression models, the positive and negative dimensions of family functioning, as perceived by the respondents, together with the global index of the family sense of functionality were selected as dependent variables. The predictors included the four KANH I factors (conformism, algorithmic behaviour, nonconformity, heuristic behaviour). The procedure took into account the results of the analysis of residues in order to eliminate cases of outliers according to the adopted criterion \pm 2 s.d. A total of seven regression analyses were performed for the 239 respondents, after eliminating outliers in the data sets for the dependent variables. Variables were subjected to logarithmic transformation and determination coefficients calculated; values significantly greater than zero $(p<.01)$, were obtained in the case of the family roles scales $(R=.31)$ and family development difficulties $(R=.27)$. Other models were found not to be suited for interpretation in terms of the regression equations obtained. Therefore, hypothesis $\mathrm{H} 1$, which assumed a positive relationship between the positive dimensions of family functioning and the components of creative attitudes was confirmed. The regression equation explaining the pathogenic roles in family included only conformism as a significant predictor $\left(R^{2}=.09\right)$. In explaining the variable family development difficulties, nonconformity and conformism were found to be most important, but with a much weaker effect size $\left(R^{2}=.07\right)$.

On the basis of these results, it can be concluded that the perception of pathogenic roles of family members is positively associated with conformism, and the perception of greater developmental difficulties in the family coincides with both lower levels of conformity $(b=-.17, p<.05)$ and nonconformity $(b=-.21, p<.01)$. Hypothesis $\mathrm{H} 2$ concerning a negative relationship between the negative dimensions of family functioning and components of creative attitudes was therefore only partially confirmed. The extent to which variation in the perception of dimensions of family functioning by the respondents can be explained in terms of the intensity of nonconformist or conformist characteristics is, however, weak.

\section{DISCUSSION}

The results of our study show that algorithmic behaviour (the cognitive component of re- 
productive attitudes) correlates positively with family cohesion, as a positive dimension of the functioning of the family system. This result is in keeping with the findings of Mendecka (2003), indicating that the family may provide a coherent system of such strength, that the individuality of its members is completely lost (among the research tools used by the author used was the KANH I Questionnaire) (see also Albert, 1994).

Excessive levels of family warmth and nurturance may inhibit a child's openness to new experiences and tolerance of risk associated with the desire for full implementation of creative possibilities (Gute, Gute, Nakamura \& Csikszentmihalyi, 2008). It can be assumed that emotional bonds of moderate strength in the family between a child that is growing up and its parents are most likely to ensure the freedom of expression, and also the full realization of his or her creative potential. It has been shown that sustainable family systems, i.e. those with moderate intensity of family cohesion, flexibility and communication are more functional than families with an extreme intensity of features forming the dimensions of the Circumplex Model (Olson, 2000).

The results of the regression analysis demonstrated the predictive role of conformism in explaining the perception of pathogenic roles in the behaviours of family members. Perhaps people with a conformist attitude are more sensitive to the diversity of the roles taken by members of their families, because of the tendency of these people to submissiveness and the search for a scheme for their own conduct, which can be difficult when there are a number of roles of an interconnected identity present in the family. Conformism is understood, amongst others, as dependence, weakness or defensiveness (Popek, 2010). In this context, the result obtained corresponds to the results of a study of retrospective self-image in dysfunctional adolescents, in whom it was found that the lower the efficiency of defending oneself in an emergency, the greater is the intensity of dysfunctional family roles in the perception of the adolescents concerned (Gaś, 1994). On the basis of regression analysis it was also found that a lower level of family developmental difficulty in the perception of adolescents is characteristic of both respondents with conformist and nonconformist attitudes, but for nonconformists the relationship is more pronounced. It can be assumed that the conformists, because of their submissiveness, do not participate in solving the kind of family problems which sometimes happen in any family system, but difficulties arising from stereotypical actions in their families accompany, in their perception, solutions to these critical situations.

It is therefore difficult to establish unequivocally the relationship between the perception of developmental difficulties in the family and the components of creative and reproductive attitudes. Indeed, focusing on the otherwise stronger relationship of nonconformi- 
ty and the perception of family developmental difficulties, the results of the research suggest that there are significant negative relationships between the intensity of family development difficulties and nonconformity as a characterological component of creative attitudes. Similar results have been obtained by Mendecka (2003). Art students with a developed creative attitude, surveyed by the author $(\mathrm{N}=349)$, were found to have, in the main, grown up in families with warm relationships,fostering an environment favourable to children. Besides, families from which creative people come, also appear to cope better with crises (Russell, 1979).

In conclusion, it must be admitted that the research results obtained do not give clear support to the assumed nature of the relationships between the manifestation of creative or reproductive attitudes and adolescents' perceptions of family functioning. Findings from the literature appear to indicate that there is little convincing and conclusive evidence of the strong influence of parents on the behaviour and personality of children and adolescents (Collins, 2000; Harris, 1995, 1998; Landau \& Weissler, 1993; Rowe, 1994). In addition, a comparison of the results of our study with other studies presented in the literature is difficult because various researchers have used heterogeneous measures of creative attitudes, respondents are of different ages, and sometimes surveys are based on relatively small samples, which may be unrepresentative, or are focused on different dimensions of family functioning (Fu, Moran, Sawyers \& Milgram, 1983).

For example, in another study on the perception of the functionality of the family system in terms of the Circumplex Model (scale FACE II) by adolescents with different levels of creative attitudes, it was found that the higher the level of creative attitudes of adolescents, the greater is the level of dysfunctionality in the family in the opinion of the respondents (Van Rossum \& Van der Loo, 1997). It should be noted, however, that the results of this research are not comparable with the results of our study and the profile of the study group was very different from the respondents in our survey. The analysis concerned the perception of family functionality by talented athletes compared with athletes with average achievements.

In our opinion, further studies should be undertaken in order to analyze the functioning of the families of adolescents with different levels of creative attitudes so that the potential of adolescents might be diagnosed more accurately, and opportunities for the implementation of this potential could be augmented. The need to use both quantitative and qualitative methods in examining the variables of family life and their relationship with the level of creative attitudes of adolescents should be considered, e.g. by having adolescents describe their life or present chronologically the most important family events in the adoles- 
cent's opinion, and have them identify the differences and similarities in their perception of other members of their family (such proposals are presented, amongst others, by Gilbert, 1993; Oskowitz \& Meulenberg-Büskens, 1997).

This would provide a more dynamic view of the parent-child relationship than is permitted from a unilateral perspective, that is, from the point of view of the adolescents. In future studies, it might also be interesting to take into account the moderating influence of personality traits of adolescents with different levels of creative approaches on the perception of the individual dimensions of their family functioning and support obtained.

\section{REFERENCES}

Albari, Q. N., Smadi, S., Bani Yassin, M. \& ALShammari, W. T. (2013). The role of school and family in developing childrens' literary creativity. International Journal of Education, 5, 136-156.

Albert, R. S. (1994). The contribution of early family history to the achievement of eminence. In N. Colangelo \& S. Assouline (Eds.), Talent development (pp. 311-360). Dayton: Ohio Psychology Press.

Csikszentmihalyi, M., Rathunde, K. \& Whalen, S. (1993). Talented teenagers: The roots of success and failure. UK: Cambridge University Press.

Bloom, B. S. (Ed.). (1985). Developing talent in young people. New York: Ballantine Books.

Collins, W. A., Maccoby, E. E., Steinberg, L., Hetherington, E. M. \& Borstein, M. H. (2000). Contemporary research on parenting. American Psychologist, 55, 218-32.

Cox, M. J. \& Paley, B. (2003). Understanding families as systems. Current Directions in Psychological Science, 12, 193-196.

Fleer, M. \& Hedegaard, M. (2010). Children's development as participation in everyday practices across different institutions. Mind, Culture \& Activity, 17, 149-168.

Fu, V. R., Moran, J. D., Sawyers, J. K. \& Milgram, R. M. (1983). Parental influence on creativity in preschool children. The Journal of Genetic Psychology, 143, 289-291.

Gaś, Z. B. (1994). Uzależnienia: skuteczność programów profilaktyki. [Addictions: the effectiveness of prophylactic programmes]. Warszawa: WSiP.

Gilbert, N. (Ed). (1993). Researching social life. London. England UK: Sage Publications, Inc.

Gute, G., Gute, D. S., Nakamura, J. \& Csikszentmihalyi, M. (2008). The early lives of highly creative persons: the influence of the complex family. Creativity Research Journal, 20, 343-357. 
Harrington, D. M., Block, J. H. \& Block, J. (1987). Testing aspects of Carl Rogers's theory of creative environments: Child-rearing antecedents of creative potential in young adolescents. Journal of Personality and Social Psychology, 52, 851-856.

Harris, J. R. (1995). Where is the child's environment? A group socialization theory of development. Psychological Review, 102, 458-489.

Harris, J. R. (1998). The nurture assumption: Why children turn out the way they do? New York: Free Press.

Helson, R. (1968). Effects of sibling characteristics and parental values on creative interest and achievement. Journal of Personality, 36, 589-607.

Hennessey, B. A. (1995). Social, environmental, and developmental issues and creativity. Educational Psychology Review, 7, 163-183.

Karwowski, M. (2013). Kwestionariusz Twórczego Zachowania KANH: (konstruktywnie krytyczna) analiza psychometryczna. In M. Kuśpit (Ed.), Barwy twórczości. [Colours of creativity] (pp. 311-360). Lublin: Wydawnictwo UMCS.

Landau, E. \& Weissler, K. (1993). Parental environment in families with gifted and nongifted children. Journal of Psychology, 127, 129-142.

Mendecka, G. (2003). Środowisko rodzinne w percepcji osób aktywnych twórczo. [Family environment in the perception of creative individuals]. Częstochowa: Wydawnictwo WSP.

Miller, B. C. \& Gerard, D. (1979). Family influences on the development of creativity in children: an integrative review. Family Coordinator, 28, 295-312.

Olson, D. (2000). Circumplex model of marital and family systems. Journal of Family Therapy, 22, 144-147.

Olszewski, P., Kulieke, M. J. \& Buescher, T. (1987). The influence of the family environment on the development of talent: a literature review. Journal for the Education of the Gifted, 11, 6-28.

Paris, R. \& Helson R. (2002). Early mothering experience and personality change. Journal of Family Psychology, 16, 172-185.

Oskowitz, B. \& Meulenberg-Buskens, I. (1997). Preparing researchers for a qualitative investigation of a particularly sensitive nature: reflections from the field. South African Journal of Psychology, 27, 83-88.

Popek, S. (2010). Kwestionariusz Twórczego Zachowania KANH. [The Creative Behaviour Questionnaire KANH]. Lublin: Wydawnictwo UMCS.

Pufal-Struzik, I. (2006). Podmiotowe i społeczne warunki twórczej aktywności artystów [Individual and social determinants of the creative activity of artists]. Kielce: Wydawnictwo Uczelniane Wszechnicy Świętokrzyskiej. 
Rostowska, T. \& Rostowski, J. (2006). Jakość życia rodzinnego w kontekście teorii systemowej. Pedagogika Rodziny, 1, 127-143.

Rowe, D. (1994). The limits of family influence: genes, experience, and behavior. New York: Guilford Press.

Van Rossum, J. H. A. \& Van der Loo, H. (1997). Gifted athletes and complexity of family. Structure: a condition for talent development? High Ability Studies, 8, 19-30.

Walberg, H. J., Rasher, S. P. \& Parkerson, J. (1980). Childhood and eminence. Journal of Creative Behavior, 13, 225-231.

Corresponding author at: Irena Pufal-Struzik, Department of Psychology, Jan Kochanowski University in Kielce, 11 Krakowska St., 25-029 Kielce, Poland.

E-mail: irenapufal@gmail.com

Corresponding author at: Agnieszka Szewczyk, Faculty of Education and Arts, Jan Kochanowski University in Kielce, 6/11 Domaniówka St., 25-413 Kielce, Poland.

E-mail: asutowicz@onet.eu 